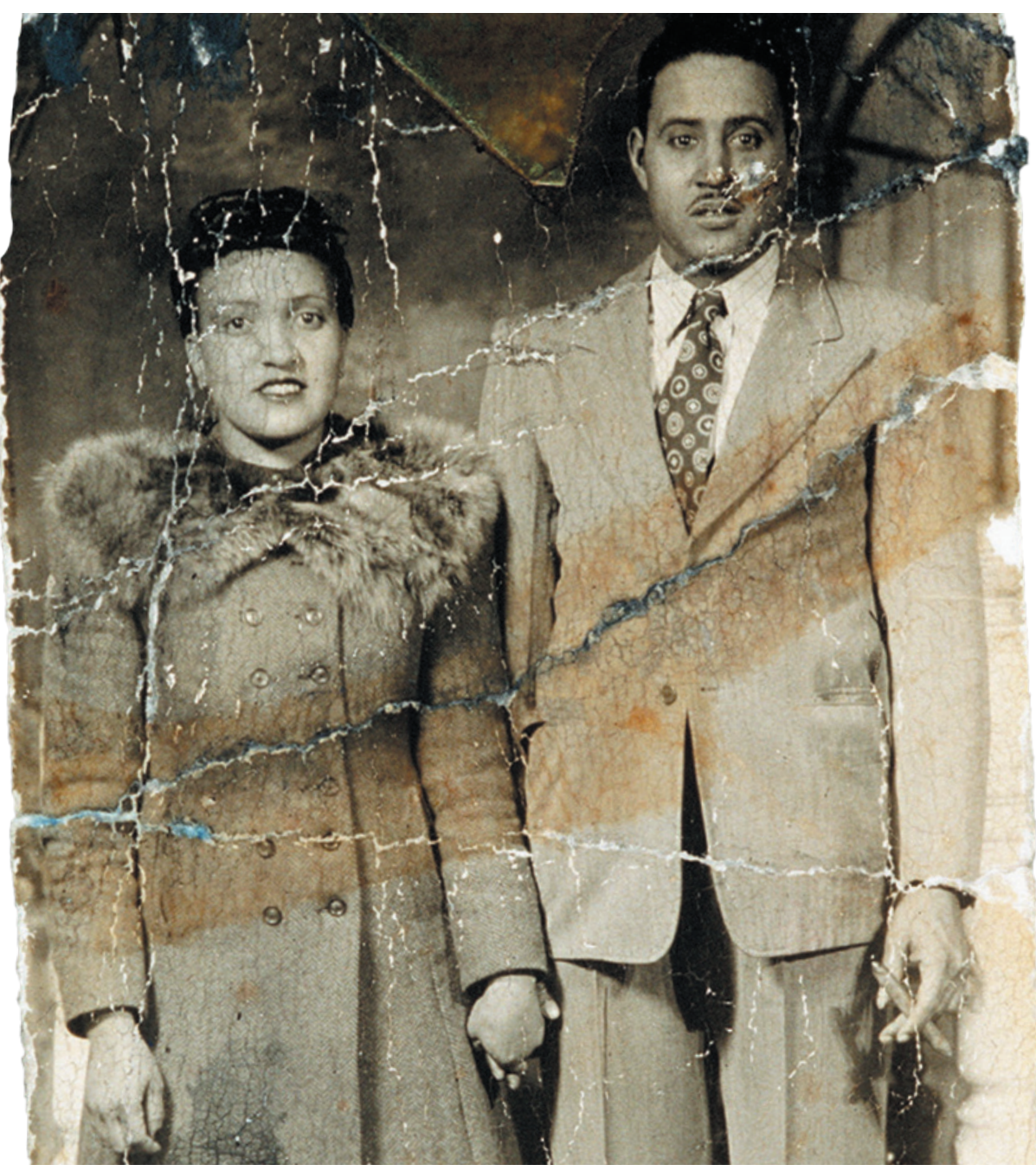

Henrietta Lacks with her husband David.

\title{
ETHICS
}

\section{Deal done over HeLa cell line}

\section{Family of Henrietta Lacks agrees to release of genomic data.}

\section{BY EWEN CALLAWAY}

$\mathrm{D}$

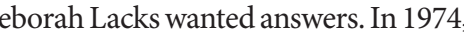
she asked a leading medical geneticist to tell her about HeLa cells, a tissue-culture cell line derived from the cancer that had killed her mother Henrietta in 1951. The researcher, who was collecting blood from the Lacks family to map HeLa genes, autographed a medical textbook he had written and said that everything she needed to know lay within its dense pages.

It would be more than 30 years before the family got a better explanation.

Now the director of the US National
Institutes of Health (NIH), Francis Collins, is trying to make up for decades of slights. Over the past four months, he has met Lacks family members to answer questions and to discuss what should be done with genome data from their matriarch's cell line.

"We wanted to get a better understanding of what information was going to be out there about Henrietta, and what information was going to be out there about us," says Henrietta's grandson David Lacks Jr. (Deborah Lacks died in 2009.) On 7 August, Collins announced that the family has endorsed case-by-case release of the information, subject to approval by a committee that will include family members (see page 141).

The consensual approach is a sea change from the dismissive treatment of the past, says Rebecca Skloot, the journalist who recounted the scene between Deborah Lacks and the researcher in her 2010 book The Immortal Life of Henrietta Lacks. "It was the first time in the very long history of HeLa cells that any scientists have sat down and devoted complete attention to explaining to the family what was going on," she says (see 'The Lacks legacy').

The agreement allows the publication of a US government-funded HeLa genome sequence as well as the re-release of data that were pulled from public view soon after publication in March because of the family's concerns. Nature's News team learned of the negotiations last month but agreed to delay coverage so as not to impede the talks. Brokered during meetings at Johns Hopkins School of Medicine in Baltimore, Maryland, the deal rekindles debates over consent and ownership of tissues, and data that arise from their study, at a time when the NIH is updating such rules.

The HeLa cell line was established in 1951 from a biopsy of a cervical tumour taken from Henrietta Lacks, a working-class AfricanAmerican woman living near Baltimore. The cells were taken without the knowledge or permission of her or her family, and they became the first human cells to grow well in a lab. They contributed to the development of a polio vaccine, the discovery of human telomerase and countless other advances. A PubMed search for 'HeLa' turns up more than 75,000 papers. "My lab is growing HeLa cells today," Collins told Nature in an interview on the NIH campus in Bethesda, Maryland. "We're using them for all kinds of gene-expression experiments, as is almost every molecular-biology lab."

On 11 March, weeks before Collins drove to Baltimore to meet the Lacks family for the first time, a team led by Lars Steinmetz at the European Molecular Biology Laboratory (EMBL) in Heidelberg, Germany, published a paper called 'The genomic and transcriptomic landscape of a HeLa cell line' (J. J. M. Landry et al. Genes Genomes Genet. http://dx.doi. org/10.1534g3.113.005777; 2013). News coverage (see go.nature.com/inxzuw) noted the link to Henrietta Lacks, but not privacy concerns.

Skloot, in a later article for The New York Times, made clear that family members were unhappy that - yet again - they had not been consulted. "I think it's private information," Henrietta's granddaughter Jeri Lacks-Whye told Nature. "I look at it as though these are my grandmother's medical records that are just out there for the world to see." The EMBL team removed the data from public access, and hoped that a solution could be reached.

As the controversy erupted, Nature was preparing to publish an even more detailed sequence of the HeLa genome, according to senior author Jay Shendure, a genome scientist 
at the University of Washington in Seattle. His team, funded by the NIH, started decoding HeLa DNA in 2011, as part of an effort to develop new sequencing techniques. They also hoped that the genome would be useful for other researchers, a motivation shared by the EMBL team. They submitted their paper to Nature in November 2012.

The paper's reviewers did not raise privacy concerns before recommending it for publication; nor did Nature, Shendure says. He considered contacting the Lacks family before publication, and restricting access. "Figuring out how to reach out to the family was very much on the table when events overtook us."

After Skloot's article on the EMBL paper came out in March, Collins learned about Shendure's NIH-funded project. He saw an opportunity. He was already at work reforming the rules that govern research on human subjects. "It looked as if this was a moment to get everybody in the same room," he says.

And so, on the evening of 8 April, Collins met a group of Henrietta Lacks' children and grandchildren for dinner and discussion at the Johns Hopkins campus. Along with Collins was his chief adviser and two mediators from the university. Skloot phoned in to the meeting, which was to be the first of three.

Collins says that family members told him how unsettling it had been to learn about HeLa cells decades after Lacks died. They peppered Collins with questions about genetic sequencing and how Lacks' cells had been used. "I felt like I was taking 'Biology 101'," says LacksWhye. Collins told them that Shendure's team might have identified the genetic change that made their grandmother's tumour so aggressive and HeLa cells so prolific. The NIH later put the family in touch with experts in clinical genetics who told them what health information could be gleaned from the genome, and the NIH offered to help family members have their own genomes sequenced and interpreted.

Collins says that he did not pressure the family to agree to the release of the HeLa genome data; he was open to leaving the NIH-funded work unpublished. But he told the family that it would be impossible to keep the data locked away. NIH researchers had calculated that 400 genomes' worth of HeLa data are already publicly available in piecemeal form - parts of projects such as the Encyclopedia of DNA Elements - and that scientists in thousands of labs around the world could easily and cheaply sequence the cell line themselves.

Some Lacks family members raised the possibility of financial compensation, Collins says. Directly paying the family was not on the table, but he and his advisers tried to think of other ways the family could benefit, such as patenting a genetic test for cancer based on HeLa-cell mutations. They could not think of any. But they could at least reassure the family that others would not make a quick buck from their grandmother's genome, because

\section{THE LACKS LEGACY}

Story of the world's most widely used human biological research tissue.

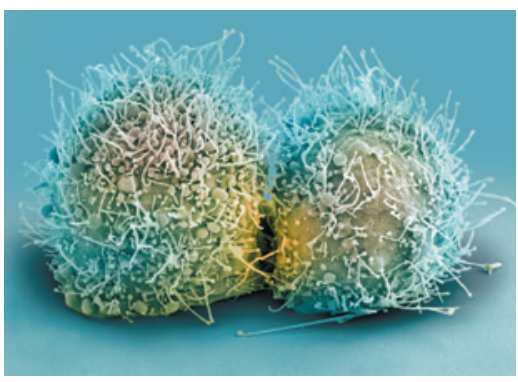

1951 Biopsy of Henrietta Lacks' tumour collected without her knowledge or consent. HeLa cell line soon established.

1971 The journal Obstetrics and Gynecology names Henrietta Lacks as HeLa source; word later spreads in Nature, Science and mainstream press.

\section{Lacks family members learn} about HeLa cells (pictured). Scientists later collect their blood to map HeLa genes, without proper informed consent.

\section{Lacks family honoured at} the first annual HeLa Cancer Control Symposium, organized by former student of scientist who isolated HeLa cells.

2013 HeLa genome published without knowledge of the family, which later endorses restricted access to HeLa genome data.

the US Supreme Court had this year ruled that unmodified genes could not be patented. Lacks-Whye says that the family does not want to dwell on money - and that her father has often said he "feels compensated by knowing what his mother has been doing for the world".

In the end, the family decided that it wanted the data to be available under a restrictedaccess system similar to the NIH dbGaP database, which links individuals' genetic make-up to traits and diseases. Researchers would apply for permission to acquire the data and agree to use them for biomedical research only, and would not contact Lacks family members. A committee that includes family members will handle requests, and papers that use the data will recognize Henrietta Lacks and her kin. The first of these papers, the NIH-funded paper, is published in this issue (see page 207).

In discussing HeLa cells and the agreement forged with the family, Collins and others often use the word "unique". No other human sample matches the cell line for ubiquity, notoriety or celebrity (Oprah Winfrey is producing a film based on the story). The NIH does not see the deal with the family as a guide to handling other human samples. "It's not going to be a precedent," says Collins' chief adviser Kathy Hudson.

But it will probably inform other cases, she adds. The US government is redrafting rules that govern the relationship between federally funded researchers and participants. New rules aim to give subjects greater say in how their tissues and personal data are used. "Going forward, I'm very much of the mind that the most appropriate way to show respect for persons is to ask," Collins says. "Ask people, 'Are you comfortable having this specimen used for future genomic research for a broad range of biomedical applications?' - if they say no, no means no."

As for the myriad other tissues out there that were obtained without consent, Collins says that it would slow science too much to ban their use. Laura Rodriguez, a policy official at the NIH who works on guidelines for genome sequencing, says that there is a low risk of donors of such samples being identified. But in January, researchers working on a genomics project showed that it is possible to identify anonymous participants - and their families - by cross-referencing their genomes with genealogy DNA databases.

Hank Greely, a biotechnology lawyer at Stanford University in California who has advised the EMBL group, says the HeLa agreement is a "good solution", but applying it to other unconsented cell lines and data would be unwieldy and impractical. "The one thing we really should be doing is making sure everything we collect from here into the future is acceptable."

Lacks-Whye has similar advice. Researchers can make major breakthroughs, she says, while still respecting the wishes of patients and their families. "Have them involved," she says. "That's not only for HeLa sequences, but anybody who participates in research." - SEE EDITORIALP.121

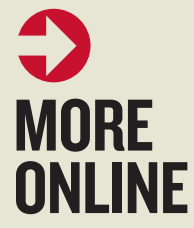

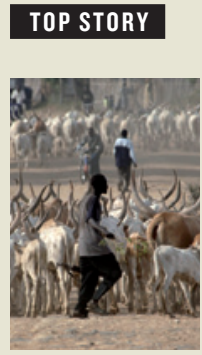

Climatic swings have incited human conflict throughout history go.nature.com/ b5nrl6

\section{MORE NEWS}

- Synthetic molecule fights TB in mice go.nature.com/ilvazz

- Genes linked to human ability to smell four scents go.nature.com/ seiwvy

- Undernourishment during development reduces fitness later in life go.nature.com/lxigvk 